\title{
Erythromelalgia: A Child With V400M Mutation in the SCN9A Gene
}

Chineze Nwebube, MS, Sabrina Bulancea, MD, Adrian Marchidann, MD, Lourdes Bello-Espinosa, MD, and Simona Treidler, MD

Neurol Genet 2021;7:e570. doi:10.1212/NXG.0000000000000570

Erythromelalgia is a rare pain syndrome caused by gain-of-function mutations of the SCN9A gene. The gene encodes $\mathrm{Na}_{\mathrm{v}} 1.7$ channels, preferentially located in the sympathetic ganglia and nociceptive sensory neurons of the dorsal root ganglia (DRG), ${ }^{1}$ that play a key role in pain modulation. ${ }^{2}$ DRG hyperexcitability leads to decreased pain threshold and increased firing frequency of pain signaling neurons. ${ }^{3}$ Clinically, this presents as recurrent, severe burning pain, redness, warmth, and often swelling of the distal extremities. Exposure to cold may provide relief but can lead to skin ulcerations. ${ }^{4}$ There is anecdotal evidence of partial relief from NSAIDS, antihistamines, and sodium channel blockers. ${ }^{5,6}$ Carbamazepine and oxcarbazepine inactivate sodium channels but have been ineffective in most patients. Only 1 family with erythromelalgia and V400M mutation in the SCN9A gene that responded to carbamazepine was reported so far. ${ }^{3}$

\section{Case Presentation}

We report a 10-year-old girl with erythromelalgia who tested positive for the V400M mutation in the SCN9A gene. Born at full term, she had normal development. Around the age of 2 , she started crying and refused to walk for days; she often walked on her tiptoes. After several hospitalizations for severe pain, she was diagnosed with viral myalgia or growing pains. The pain gradually worsened with age. Occasionally, she experiences burning of the fingertips and flushing of the face and ears. The flairs occur at least once a month for several days at a time, oftentimes waking her from sleep. Exposure to high temperature and humidity, spicy foods, and fever aggravates pain, while cooling measures alleviate it. Frequent use of ice packs, fans, A/C, and swims in cool water led to skin ulcerations. Gabapentin, acetaminophen, naproxen, and massages provided little relief.

She has no siblings. There is no family history of similar symptoms, rheumatological, autoimmune, paroxysmal pain disorders or insensitivity to pain. Autoimmune-related peripheral neuropathy was ruled out by full rheumatological workup. Nerve conduction studies did not reveal generalized peripheral neuropathy. EEG was normal. Erythromelalgia was diagnosed.

Genetic testing using next-generation sequencing confirmed by multiplex ligation-dependent probe amplification was positive for mutation in the SCN9A gene (c.1198G>A, p.Val400Met), characterized as likely pathogenic. Testing of her parents was negative for this mutation. Lidocaine cream and extended release carbamazepine $100 \mathrm{mg}$ twice a day provided partial relief. Carbamazepine was titrated to $200 \mathrm{mg} 3$ times daily without improvement. After a flair of pain lasting for several days, she received $0.2 \mathrm{mg} / \mathrm{kg} / \mathrm{h}$ ketamine infusion for 3 days. She was pain free for 7 days.

\author{
Correspondence \\ Dr. Treidler \\ streidler@maimonidesmed.org
}


After 14 days, because of recurrent pain, lidocaine drip of 4 $\mathrm{mg} / \mathrm{kg}$ over 3 hours was administered with complete relief. Mexiletine $150 \mathrm{mg}$ orally twice daily was added at discharge. Despite outpatient treatment with mexiletine, ketamine lozenges, and intermittent ketamine drips, the pain gradually recurred at a severity of $10 / 10$ within a few weeks. Subsequently, a lidocaine drip was initiated at $16 \mu \mathrm{g} / \mathrm{kg} / \mathrm{h}$, at increments of $20 \%$ every 8 hours, and a goal pain level of $4 / 10$. Simultaneously, mexiletine was titrated to $650 \mathrm{mg} / \mathrm{d}$ orally in 3 divided doses. After 2 weeks, lidocaine was tapered off, and she was discharged with minimal nocturnal pain.

\section{Discussion}

The V400M mutation in SCN9A was reported as likely pathogenic in 1 family with erythromelalgia which responded very well to carbamazepine. ${ }^{3}$ Our patient shares the same mutation. This provides further evidence that this mutation is associated with erythromelalgia. Her parents tested negative for the mutation, raising the possibility of a de novo mutation.

In contrast to the previously described family, our patient responded poorly to carbamazepine. Similarly to other patients with unexplored genetic mutations, ${ }^{7}$ our patient required IV lidocaine while transitioning to oral mexiletine.

Electrophysiologic studies in the presence of the V400M mutation showed that carbamazepine normalizes both the activation and inactivation curves of the mutant sodium channels without affecting the wild-type channels. ${ }^{2,3}$ Rather than blocking the sodium channels, carbamazepine has a modulating effect on the V400M variant. The varied responsiveness to carbamazepine may be explained by the distinct mutations participating in different steps of channel gating. ${ }^{2}$

In summary, we describe a patient with erythromelalgia and V400M mutation in SCN9A who responded inadequately to carbamazepine and required IV ketamine or lidocaine for adequate pain relief while transitioned successfully to oral mexiletine. This report of C.1198G $>$ A(V400M) mutation brings additional support for classification of this variant as pathogenic and provides insight into effective pharmacotherapy.

\section{Study Funding}

No targeted funding reported.

\section{Disclosure}

The authors report no disclosures relevant to the manuscript. Go to Neurology.org/NG for full disclosures.

\section{Publication History}

Received by Neurology: Genetics October 14, 2020. Accepted in final form February 3, 2021.

Appendix Authors

\begin{tabular}{lll}
\hline Name & Location & Contribution \\
\hline $\begin{array}{l}\text { Chineze } \\
\text { MS }\end{array}$ & $\begin{array}{l}\text { Stony Brook University } \\
\text { Hospital, NY }\end{array}$ & $\begin{array}{l}\text { Drafting/revision of the } \\
\text { manuscript for content, } \\
\text { including medical writing for } \\
\text { content }\end{array}$ \\
$\begin{array}{l}\text { Sabrina } \\
\text { Bulancea, } \\
\text { MD }\end{array}$ & $\begin{array}{l}\text { Pneumophtisiology } \\
\text { Clinical Hospital, } \\
\text { Brasov, Romania }\end{array}$ & $\begin{array}{l}\text { Drafting/revision of the } \\
\text { manuscript for content, } \\
\text { including medical writing for } \\
\text { content }\end{array}$ \\
\hline $\begin{array}{l}\text { Adrian } \\
\text { Marchidann, } \\
\text { MD }\end{array}$ & $\begin{array}{l}\text { Kings County Hospital, } \\
\text { Brooklyn, NY }\end{array}$ & $\begin{array}{l}\text { Drafting/revision of the } \\
\text { manuscript for content, } \\
\text { including medical writing for } \\
\text { content }\end{array}$ \\
\hline $\begin{array}{l}\text { Lourdes } \\
\text { Bello- }\end{array}$ & $\begin{array}{l}\text { Stony Brook University } \\
\text { Hospital, NY }\end{array}$ & $\begin{array}{l}\text { Drafting/revision of the } \\
\text { manuscript for content, } \\
\text { including medical writing for } \\
\text { content }\end{array}$ \\
\hline $\begin{array}{l}\text { Simona } \\
\text { Treidler, MD }\end{array}$ & $\begin{array}{l}\text { SUNY Downstate, } \\
\text { Maimonides Medical } \\
\text { Center, Brooklyn, NY }\end{array}$ & $\begin{array}{l}\text { Drafting/revision of the } \\
\text { manuscript for content, } \\
\text { including medical writing for } \\
\text { content; major role in the } \\
\text { acquisition of data; study } \\
\text { concept or design }\end{array}$ \\
\hline
\end{tabular}

\section{References}

1. Skeik N, Rooke TW, Davis MD, et al. Severe case and literature review of primary erythromelalgia: novel SCN9A gene mutation. Vasc Med 2012;17:44-49.

2. Yang Y, Dib-Hajj SD, Zhang J, et al. Structural modelling and mutant cycle analysis predict pharmacoresponsiveness of a Na v 1.7 mutant channel. Nat Commun 2012;3: $1-2$.

3. Fischer TZ, Gilmore ES, Estacion M, et al. A novel Nav1. 7 mutation producing carbamazepine-responsive erythromelalgia. Ann Neurol 2009;65:733-741.

4. Waxman SG, Dib-Hajj S. Erythromelalgia: molecular basis for an inherited pain syndrome. Trends Mol Med 2005;11:555-562.

5. Novella SP, Hisama FM, Dib-Hajj SD, Waxman SG. A case of inherited erythromelalgia. Nat Clin Pract Neurol 2007;3:229-234.

6. Sheets PL, Jackson JO, Waxman SG, Dib-Hajj SD, Cummins TR. A Nav1. 7 channel mutation associated with hereditary erythromelalgia contributes to neuronal hyperexcitability and displays reduced lidocaine sensitivity. J Physiol 2007; 581:1019-1031.

7. Elgueta F, de la Cuadra-Fontaine JC, Clede L, Fierro C, Valderrama A. Erythromelagia: a rare and hard-to-treat condition: a 9-year-old boy responsive to intravenous lidocaine and oral mexilitene. Pain Med 2013;14:311-312. 


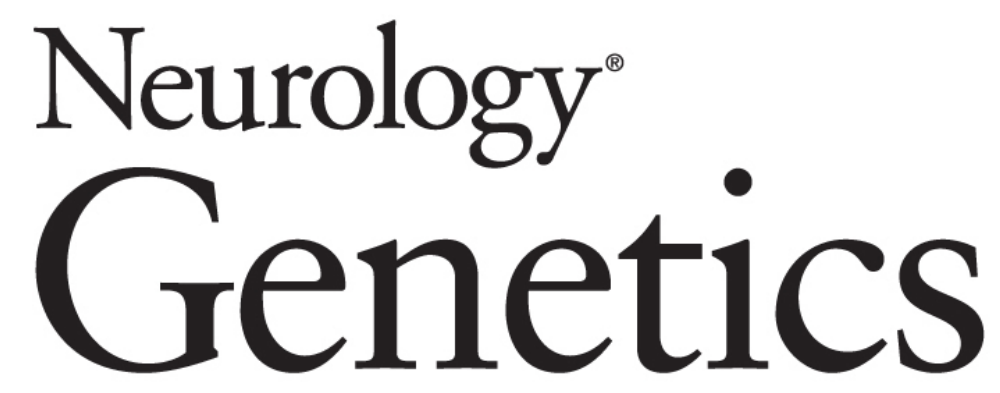
Erythromelalgia: A Child With V400M Mutation in the $S C N 9 A$ Gene
Chineze Nwebube, Sabrina Bulancea, Adrian Marchidann, et al.
Neurol Genet 2021;7;
DOI 10.1212/NXG.0000000000000570

This information is current as of March 1, 2021

\begin{abstract}
Updated Information \& Services

including high resolution figures, can be found at: http://ng.neurology.org/content/7/2/e570.full.html

References

This article cites 7 articles, 0 of which you can access for free at: http://ng.neurology.org/content/7/2/e570.full.html\#\#ref-list-1

Permissions \& Licensing its entirety can be found online at: http://ng.neurology.org/misc/about.xhtml\#permissions

Reprints

Information about ordering reprints can be found online: http://ng.neurology.org/misc/addir.xhtml\#reprintsus
\end{abstract} Information about reproducing this article in parts (figures,tables) or in

Neurol Genet is an official journal of the American Academy of Neurology. Published since April 2015, it is an open-access, online-only, continuous publication journal. Copyright Copyright $\odot 2021$ The Author(s). Published by Wolters Kluwer Health, Inc. on behalf of the American Academy of Neurology.. All rights reserved. Online ISSN: 2376-7839.

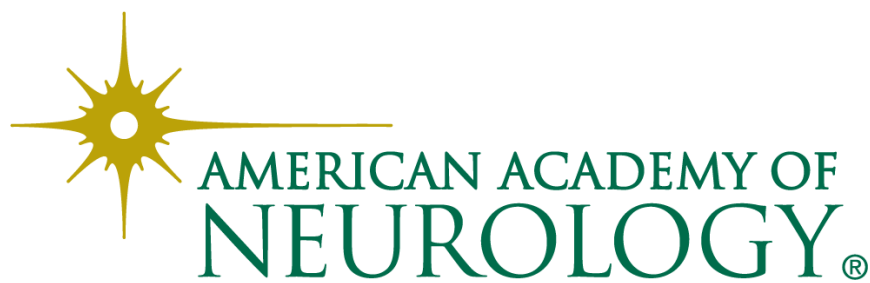

